\title{
Size and Growth of the Eyes of the Troglobitic Salamander Typhlotriton spelaeus
}

\author{
by
}

\author{
Joseph C. BESHARSE*** and Ronald A. BRANDON*
}

The eyes of troglobitic urodeles are reduced in size compared to their epigean relatives (reviewed by Brandon, 1971a), but in no case is a thorough analysis of growth and variation in size available. Measurements of the eyes of Eurycea tridentifera (Mitchell and Reddell, 1965) and Haideotriton wallacei (Brandon, 1968) indicate that one parameter of eye reduction of these animals is considerable individual variation and bilateral asymmetry. The significance of these observations is not clear, however, since in no case has it been determined whether or not such variation reflects genotypic differences. The inherent difficulties in genetic analysis among urodele amphibians preclude a quick answer to this question.

Typhlotriton spelaeus is the only troglobitic urodele that attains sexual maturity after metamorphosis; the others are paedogenetic (Brandon, 1966; 1971a). In addition, $T$. spelaeus larvae have functional eyes that usually degenerate after metamorphosis (Eigenmann and Denny, 1900; Stone, 1964; Besharse, 1972). These observations show that the minimal genotype necessary for the development of functional eyes is present in $T$. spelaeus and that such genetic factors affecting degeneration as may be discovered must have their effect on a terminal developmental stage. We have suggested (Besharse, 1972; Besharse and Brandon, in preparation) that structural degeneration of the eyes of $T$. spelaeus results from generalized cessation of eye growth and maintenance. Our observations on eye size and its variation are compatible with that hypothesis.

In the present report we analyze growth and variation in size of $T$. spelaeus eyes compared to those of the more visually oriented species Eurycea lucifuga. Eyes of larval $T$. spelaeus are smaller than those of $E$. lucifuga at the beginning of the larval growth period but, in most cases, increase in size at a rate (relative to body size) comparable to those of E. lucifuga during larval life. Postmetamorphic cessation of eye growth in $T$. spelaeus, during the time when the eyes are degenerating structurally, is accompanied by increased individual variation and bilateral asymmetry of eye size.

\footnotetext{
*) Department of Zoology, Southern Illinois University, Carbondale, Illinois 62901

***) Present address: Department of Biology, Old Dominion University, Norfolk, Virginia 23508
} 


\section{MATERIALS AND METHODS}

Gross morphological examinations and measurements were made on $168 T$. spelaeus and 155 E. lucifuga, all from Shannon, Pulaski, and Ripley cos., Missouri, now in the Zoological Research Museum of Southern Illinois University at Carbondale. These animals were killed in Chloretone, fixed in 10\% formalin, and preserved in $65 \%$ ethyl alcohol. Most of the postmetamorphic sample of T. spelaeus came from Wet Cave, Shannon Co., Mo.; additional data are available on this sample (Brandon, 1971b).

The skin immediately above the eye was cut with iridectomy scissors and reflected laterally and posteriorly, exposing the dorsal surface of the eyeball. Orbital connective tissue was separated and the greatest diameter of the eyeball was measured (perpendicular to the visual axis) with a calibrated occular micrometer in a binocular microscope at $30 \mathrm{X}$. Snout-vent length of each animal was recorded; all lengths given were measured from the snout to the posterior end of the vent.

Gonads of all postmetamorphic $T$. spelaeus were examined so that variation in eye size could be related to sex and postmetamorphic age. Females were considered immature if the oviduct was thin, uncoiled, and lay dorsal to an ovary containing small $(<1.0 \mathrm{~mm}$ diameter), yolkless ova. Females with large $(1.5$ to $3.0 \mathrm{~mm}$ diameter), yolked ovarian ova and hypertrophied, coiled oviducts, and those with small ovarian ova $(<1.5 \mathrm{~mm})$ and moderately enlarged, laterally displaced oviducts were considered mature. All postmetamorphic male $T$. spelaeus examined were sexually mature. Male $T$. spelaeus have a multiple testis; for each individual the number of testis lobes was counted. In many other salamanders that have a multiple testis (Humphrey, 1922, 1926; Organ, 1961) the number of lobes reflects the number of previous breeding years with a yearly change in testis morphology and an increase of one in number of lobes every other year. Since the annual testicular cycle of $T$. spelaeus resembles that of other salamanders (Brandon, 1971b), a similar relationship between age and testis lobation probably exists in $T$. spelaeus and the number of testis lobes reflects the relative postmetamorphic age of males; males with three lobes are older than those with one or two.

In analyzing the relationship of eye diameter to body length, use was made of the allometric equation, $Y=b X^{\alpha}$, which yields a straight line when plotted on double logarithmic coordinates. The value of $b$ is the $Y$-intercept (value of $Y$ when $\mathrm{X}=1$ ) and $\alpha$ represents the ratio of the geometric rates of increase of $Y$ and $X$. The equation was fitted by least squares, using a Hewlett-Packard Calculator (9100B), yielding estimates of $b, \alpha$, and the correlation coefficient (r). The standard error of the estimate of $\alpha(\mathrm{S} \alpha)$ was calculated (see Brody, 1945, p. 398). For comparison of relative dispersion about mean eye diameter in the two species, coefficients of variation (V) along with 95\% confidence limits were calculated (Simpson, Roe and Lewontin, 1960). 


\section{RESULTS}

The eyes of larval E. lucifuga were about two to three times as large as those of $T$. spelaeus of comparable size. In both species eyes were relatively larger in small larvae, indicating a negative allometric relationship of eye to body size. Comparison of allometric coefficients (Table 1) of larvae shows 1) that allometric coefficients for larval $T$. spelaeus are variable from one locality to another, 2) that two Pulaski Co. populations have lower coefficients and one has a higher coefficient than $E$. lucifuga, and 3) that the coefficient for larvae from Wet Cave is considerably lower than those for either larval T. spelaeus from Pulaski Co. or for larval E. lucifuga. The lower coefficient for the Wet Cave population reflects the smaller eye size of large larvae in these animals. The similarity of allometric coefficients in four of five populations of $T$. spelaeus to that of E. lucifuga indicates that in these populations small eye size results primarily from formation of a small eye rudiment at the beginning of the larval growth period. Decreased relative growth of the eye contributes further to small eye size in the Wet Cave population of T. spelaeus (see Fig. 1), and perhaps also in the Bat Cave and Bruce Cave populations.

In $E$. lucifuga the allometric coefficients $(\alpha)$ were lower in postmetamorphic animals than in larvae (Fig. 1; Table 1) suggesting a slight decrease in relative growth of the eye after metamorphosis. In contrast, postmetamorphic $T$. spelaeus (sample from Wet Cave) deviated from the simple allometric relationship of eye diameter to body length established in larvae, and this deviation was accompanied by increased variability of eye size (Fig. 1). Observations on a small sample of postmetamorphic $T$. spelaeus from Pulaski Co. suggest that the same is true of these animals. Three factors appear to increase variability: 1) postmetamorphic cessation of eye growth and reduction of body growth (Table 2), 2) wide range of variability of body size at metamorphosis, and 3) postmetamorphic changes in eye shape.

1 . Body and eye growth are slight in postmetamorphic T. spelaeus. Among male $T$. spelaeus with one to three testis lobes there was a slight but insignificant increase in body size and no significant increase in eye size (Table 2). Mature females were slightly larger than immature females, but eye size did not differ significantly. Because of the restriction of postmetamorphic growth and attainment of sexual maturity soon after metamorphosis, size at metamorphosis and size at sexual maturity are about the same.

2. In $T$. spelaeus there is a wide range of body sizes at metamorphosis. $E$. lucifuga and $T$. spelaeus differ in size at metamorphosis and in the extent of postmetamorphic increase in body size (Fig. 1; see also Brandon, 1966, 1970; Bishop, 1943). E. lucifuga transforms at a snout-vent length of $30-35 \mathrm{~mm}$ and may double in length during postmetamorphic growth; throughout this time its eyes increase in size at a regular rate. In contrast, there is broad overlap of body sizes of larval $(13-54 \mathrm{~mm})$ and postmetamorphic $(38-57 \mathrm{~mm}) T$. spelaeus, both between populations and within populations. Since metamorphosis may take place over a broad range of body sizes, and since their eyes do not increase in size after metamorphosis (Table 2), eye size in postmetamorphic $T$. spelaeus is more variable than in larvae. 


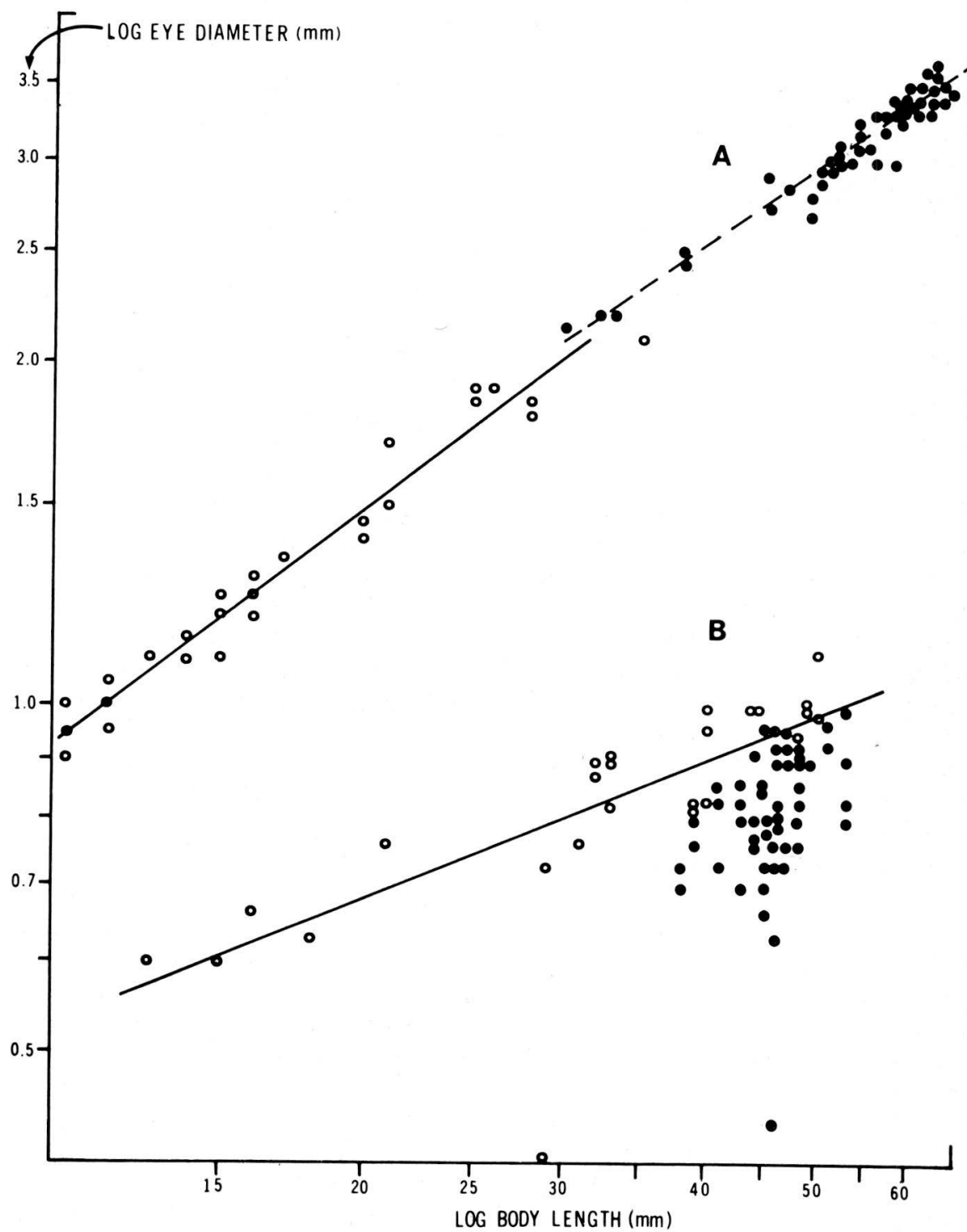

Fig. 1. Double logarithmic plot of eye diameter against body length for samples of Typhlotriton spelaeus and Eurycea lucifuga from Wet Cave, Shannon Co., Missouri showing a lowered regression slope for $T$. spelaeus larvae and a deviation among postmetamorphic $T$. spelaeus from the relationship established in larvae. A. E. lucifuga, 32 larval and 55 transformed. B. T. spelaeus, 18 larval and 43 transformed. Both eyes plotted. Duplicate data points omitted. Open circles, larvae; closed circles, postmetamorphic animals. Solid lines, regression slope for larvae. Broken line, regression slope for postmetamorphic $E$. lucifuga. 
Table 1. Allometric coefficients in larval and postmetamorphic Eurycea lucifuga and Typhlotriton spelaeus. All localities are in Missouri. Symbols are as follows: $\mathrm{N}$, number of eyes; $\mathrm{b}$, Y-intercept; $\alpha$, allometric coefficient; $\mathrm{S} \alpha$, standard error of estimate of $\alpha ; \mathrm{r}$, correlation coefficient.

\begin{tabular}{|c|c|c|c|c|c|c|}
\hline \multicolumn{2}{|c|}{ SAMPLE } & $\mathrm{N}$ & $\mathrm{b}$ & $\alpha$ & $\mathrm{S} \alpha$ & $r$ \\
\hline \multirow{6}{*}{ LARVAE } & $\begin{array}{l}\text { Eurycea lucifuga } \\
\text { Wet Cave } \\
\text { Shannon Co. }\end{array}$ & 64 & 0.155 & 0.756 & 0.040 & 0.986 \\
\hline & $\begin{array}{l}\text { Typhlotriton spelaeus } \\
\text { Wet Cave } \\
\text { Shannon Co. }\end{array}$ & 36 & 0.203 & 0.403 & 0.136 & 0.792 \\
\hline & $\begin{array}{l}\text { Bat Cave } \\
\text { Pulaski Co. }\end{array}$ & 20 & 0.112 & 0.638 & 0.076 & 0.931 \\
\hline & $\begin{array}{l}\text { Bruce Cave } \\
\text { Pulaski Co. }\end{array}$ & 14 & 0.120 & 0.605 & 0.035 & 0.991 \\
\hline & $\begin{array}{l}\text { Tunnel Cave } \\
\text { Pulaski Co. }\end{array}$ & 28 & 0.062 & 0.775 & 0.058 & 0.850 \\
\hline & $\begin{array}{l}\text { Pikes Peak Cave } \\
\text { Pulaski Co. }\end{array}$ & 16 & 0.042 & 0.899 & 0.060 & 0.927 \\
\hline \multirow{3}{*}{$\begin{array}{l}\text { TRANS- } \\
\text { FORMED }\end{array}$} & $\begin{array}{l}\text { Eurycea lucifuga } \\
\text { Wet Cave } \\
\text { Shannon Co. }\end{array}$ & 110 & 0.201 & 0.688 & 0.025 & 0.977 \\
\hline & $\begin{array}{l}\text { Lewis Cave } \\
\text { Ripley Co. }\end{array}$ & 134 & 0.292 & 0.595 & 0.033 & 0.926 \\
\hline & $\begin{array}{l}\text { Typhlotriton spelaeus } \\
\text { Wet Cave } \\
\text { Shannon Co. }\end{array}$ & 86 & 0.089 & 0.580 & 0.111 & $0.348^{1}$ \\
\hline
\end{tabular}

1 Not significantly different from zero.

Table 2. Comparison of body size and eye size in samples of male and female Typhlotriton spelaeus of varying relative age showing that postmetamorphic growth is restricted. Animals from Wet Cave Shannon Co., Missouri.

Animals

BODY LENGTH $(\mathrm{mm})$

\begin{tabular}{lrrr}
\hline Males $^{2}$ & & & \\
1 & 6 & $44.2 \pm 4.4$ & $0.878 \pm 0.123$ \\
2 & 19 & $46.8 \pm 1.0$ & $0.901 \pm 0.037$ \\
3 & 18 & $47.3 \pm 1.5$ & $0.867 \pm 0.044$
\end{tabular}

Females

Immature

20

$42.8 \pm 1.6$

$0.808 \pm 0.042$

Mature

37

$45.5 \pm 0.9$

$0.835 \pm 0.028$

1 Mean plus or minus $95 \%$ confidence limit.

2 Number of testis lobes given. 


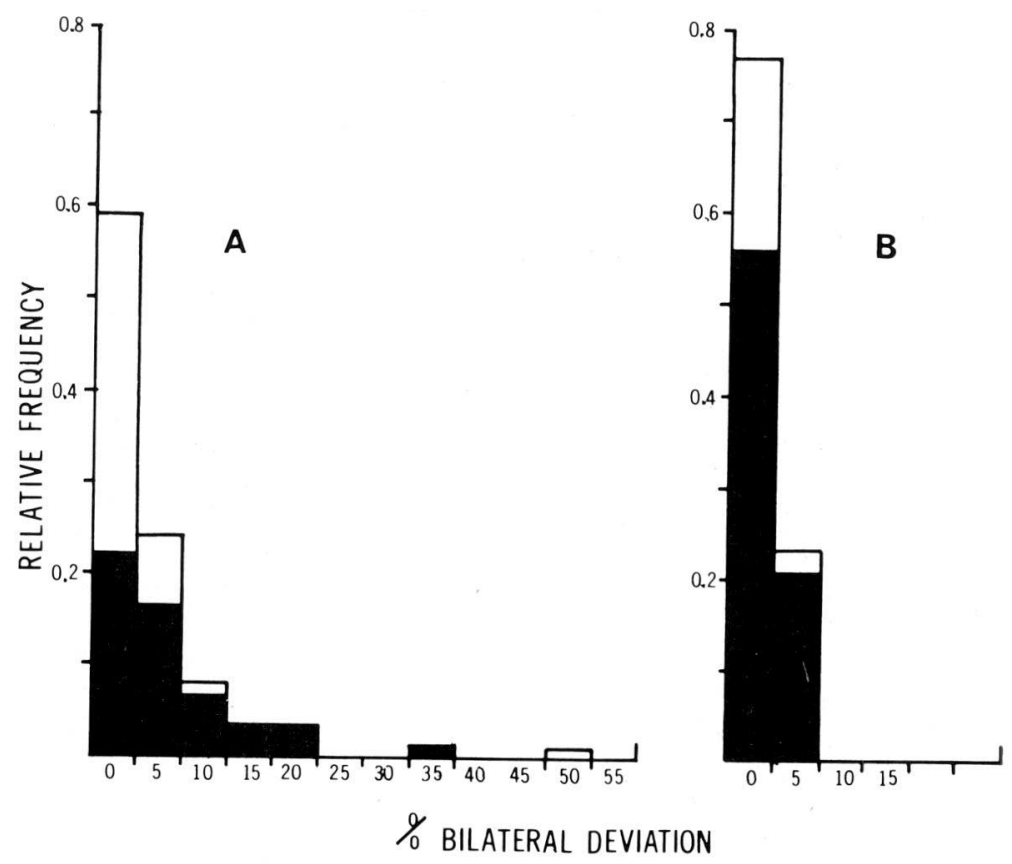

Fig. 2. Histograms showing greater frequency of bilateral asymmetry of eyes of Typhlotriton spelaeus compared to Eurycea lucifuga. A. 87 T. spelaeus from Shannon and Pulaski cos., Missouri. B. 154 E. lucifuga from Shannon and Ripley cos., Missouri. Shaded areas represent postmetamorphic animals; clear areas represent larvae. Except for zero, deviation interval is five percent.

3. Actually, larval T. spelaeus eyes measured larger than those of postmetamorphic animals of the same size (Fig. 1) suggesting reduction of eye size after metamorphosis. However, eyes changed shape during early metamorphosis becoming more spherical (Besharse, 1972; Besharse and Brandon, in preparation). These shape changes were quite variable even bilaterally and, consequently, contributed to increased variability and bilateral asymmetry of eye size, and perhaps to the apparent postmetamorphic decrease in eye size.

Bilateral asymmetry of eye size was greater in T. spelaeus than in E. lucifuga (Fig. 2), particularly in postmetamorphic animals. Sixteen percent of all $T$. spelaeus (Fig. 2A) showed deviations greater than five percent, whereas no E. lucifuga deviated more than five percent; most deviations in E. lucifuga were less than two percent. In both $T$. spelaeus and E. lucifuga, the frequency of deviation was greater in post-metamorphic animals than in larvae (Fig. 2), indicating that asymmetry usually develops after metamorphosis.

Individual variability of eye size in postmetamorphic $T$. spelaeus, expressed as relative dispersion about mean eye size, was significantly greater than in $E$. lucifuga (Table 3). Values of $\mathrm{V}$ were low in E. lucifuga, and were higher in males than in 
females. In $T$. spelaeus, values of $\mathrm{V}$ were two to three times higher than in $E$. lucifuga, and males did not differ greatly from females. Male and female $T$. spelaeus did differ, however, in mean eye size (Table 3).

Table 3. Coefficients of variation (V) for measurements of eye diameter showing that variation in adult Typhlotriton spelaeus is greater than in Eurycea lucifuga. All animals from Wet Cave, Shannon Co., Missouri.
SAMPLE
$\mathrm{N}$
$\overline{\mathrm{X}}$
$\mathrm{V} \pm 95 \%$

Eurycea lucifuga

59-65 mm

$\begin{array}{lccc}\text { males } & 28 & 3.40 & 3.20 \pm 0.84 \\ \text { females } & 28 & 3.41 & 1.60 \pm 0.42 \\ \begin{array}{l}\text { Typhlotriton spelaeus } \\ \text { males }\end{array} & & & \\ \text { females } & 22 & 0.90 & 6.21 \pm 1.84 \\ & 14 & 0.83 & 8.86 \pm 3.28\end{array}$

1 Coefficient of variation plus or minus $95 \%$ confidence limit.

\section{DISCUSSION}

In larval $T$. spelaeus eyes grow by negative allometry, but in postmetamorphic $T$. spelaeus cessation of eye growth is accompanied by increased individual variability and bilateral asymmetry of eye size. These findings along with the observation that eyes ordinarily degenerate structurally after metamorphosis (Eigenmann and Denny, 1900; Stone, 1964; Besharse, 1972; Besharse and Brandon, in preparation) are consistent with the hypothesis (Besharse and Brandon, in preparation) that postembryonic eye degeneration in $T$. spelaeus results from a generalized cessation of eye growth and maintenance.

Negative allometry in itself contributes little to reduction of eye size in $T$. spelaeus. In contrast to the situation found in anurans (deJongh, 1967) and fish (Martin, 1949; Heuts, 1951, 1953) negative allometry of eye size appears to be common among urodeles (Twitty and Schwind, 1931; Twitty and Elliot, 1934; Huxley, 1932). In larval T. spelaeus, allometric coefficients for four of five populations are comparable to that of E. lucifuga, although eyes are only about one half as large as those of E. lucifuga of comparable size. Thus, the small eye size in $T$. spelaeus results primarily from formation of a small eye rudiment prior to the larval period. Reduced relative growth of eyes contributes further to smaller relative eye size particularly in the Wet Cave population.

Larval and postmetamorphic T. spelaeus from caves in Pulaski Co. have larger eyes (both absolute and relative to body size) and attain larger body sizes than those from Shannon Co.; differences which are reflected in allometric coefficients 
for larval eyes. These populational differences may result from differences in absolute growth which in turn may be related to local differences in the abundance of food. It was concluded previously that food is scarce in Wet Cave (Brandon, $1971 b$ ), and subsequent observations support that conclusion. All of the caves sampled in Pulaski Co. appear to have a greater abundance of food appropriate for salamander larvae as evidenced by large amounts of organic debris, bat guano, and large populations of aquatic crustaceans. It is thus possible that smaller body size and smaller relative size of eyes among Wet Cave animals results from nutritional factors.

Although eyes of larval $T$. spelaeus are somewhat more variable than those of larval $E$. lucifuga, a dramatic increase in variability occurs after metamorphosis, during which time the eyes are degenerating (Besharse, 1972; Besharse and Brandon, in preparation). It appears that multiple factors associated with body growth and eye degeneration contribute to increased variation. Thus, cessation of growth and maintenance of eyes, variation in body size and thus eye size at metamorphosis, and variable shape changes all have effects. The extent to which this variability reflects intra-populational genetic differences remains uncertain.

However, three observations suggest that a significant fraction of the observed variability reflects phenotypic differences. First, genetic modifications controlling eye development are limited inasmuch as development of functional eyes is characteristic of larvae. Second, bilateral asymmetry which reflects phenotypic variation is extensive only after metamorphosis. Third, eye degeneration and to a lesser extent eye size are influenced by light and darkness (Besharse, 1972). In addition, an influence of food supply on eye and body growth is possible.

The consistency with which eyes develop in larvae and degenerate after metamorphosis (Eigenmann and Denny, 1900; Stone, 1964; Besharse, 1972; Besharse and Brandon, in preparation) points strongly toward the view that differential selective pressures act on larvae and adults. Of the troglobitic urodeles, $T$. spelaeus is uniquely adapted to utilize a wide segment of the cave biotope, including aquatic, terrestrial, light, and dark zones. Larvae are often found outside of caves and in entranceways, where they can utilize food sources not available to adults. Dispersal of larvae by way of epigean streams may be important to the species. Adults, however, appear to be restricted to the dark zones of caves. The selective advantage gained by degeneration of eyes after metamorphosis remains elusive. The classical argument of energy economy (see Barr, 1968), as it pertains to eye development, is inapplicable since eyes do develop and become functional in larvae. Eye degeneration, however, occurs as animals attain sexual maturity when energy requirements are much increased, particularly in females. Thus, it is possible that selection for overall energy economy would cause reallocation of energy resources in adults, one aspect of which would be in failure to maintain eyes. 


\section{SUMMARY}

The eyes of larval $T$. spelaeus grow by negative allometry, but in allometric coefficients they are not greatly different from $E$. lucifuga. The major differences in eye size, both absolute and relative to body size, between $T$. spelaeus and $E$. lucifuga are established prior to the larval growth period. The eyes of $T$. spelaeus cease to grow at metamorphosis and are reduced in size thereafter. In addition, there is increased individual variability and bilateral asymmetry of eye size in adult $T$. spelaeus compared to both adult $E$. lucifuga and larval $T$. spelaeus. This variability, expressed as relative dispersion about mean eye size, is significantly greater than in E. lucifuga, and appears to result from three factors: 1) postmetamorphic cessation of eye growth, 2) wide variation in body size and eye size at metamorphosis, and 3) postmetamorphic shape changes and reduction of eye size.

\section{RESUME}

La croissance des yeux de la larve de $T$. spelaeus est allométrique négative, mais avec des coefficients peu différents de ceux de $E$. lucifuga. Entre $T$. spelaeus et $E$. lucifuga, les principales différences de la taille de l'oeil, tant absolute que relative à celle du corps, ont été établies avant la période de croissance larvaire. Les yeux de T. spelaeus cessent de croitre à la métamorphose et sont, par la suite, de taille réduite. De plus, l'adulte de $T$. spelaeus montre une variabilité individuelle plus grande et une asymétrie bilatérale de la taille de l'oeil, comparativement à l'adulte d'E. lucifuga et à la larve de $T$. spelaeus. Cette variabilité, qui s'exprime par une dispersion relative autour de la taille moyenne de l'oeil, est significativement plus grande que chez $E$. lucifuga et semble due à trois facteurs: 1) arrêt de croissance de l'oeil après métamorphose 2) grande variation de la taille du corps et de la taille de l'oeil lors de la métamorphose et 3 ) changement de la forme après métamorphose et réduction de la taille de l'oeil.

\section{ACKNOWLEDGEMENTS}

We thank J. S. Garton, J. R. Holsinger, and T. L. Poulson for critical suggestions on this manuscript, and J. Kezer for use of his field and laboratory notes on Typhlotriton spelaeus. This paper is based on a part of a dissertation submitted by the senior author in partial fulfillment of the requirements for a $\mathrm{Ph}$. D. degree at Southern Illinois University at Carbondale.

\section{REFERENCES}

BARR, T. C. 1968. Cave ecology and the evolution of troglobites, p. 35-102. In Th. Dobzhansky, M. K. Hecht, and W. C. Steere, [eds.], Evolutionary Biology, Vol. 2. AppletonCentury-Crofts, New York. 
BESHARSE, J. C. 1972. Postembryonic eye degeneration in the troglobitic salamander Typhlotriton spelaeus. Ph. D. Dissertation, Southern Illinois University at Carbondale, 151 p.

BISHOP, S. C. 1943. Handbook of salamanders. Comstock Publishing Co., Ithaca, New York. $555 \mathrm{p}$.

BRANDON, R. A. 1966. A reevaluation of the status of the salamander, Typhlotriton nereus Bishop. Copeia. 1966: 555-561.

BRANDON, R. A. 1968. Structure of the eye of Haideotriton wallacei, a North American troglobitic salamander. J. Morphol. 124: 345-352.

BRANDON, R. A. 1970. Typhlotriton and T. spelaeus (Revised). Catalogue of American Amphibians and Reptiles. 84.1-84.2.

BRANDON, R. A. 1971a. North American troglobitic salamanders: some aspects of modification in cave habitats, with special reference to Gyrinophilus palleucus. Bull. Nat. Speleol. Soc. 33: 1-21.

BRANDON, R. A. 1971b. Correlation of seasonal abundance with feeding and reproductive activity in the grotto salamander (Typhlotriton spelaeus). Amer. Mid. Natur. 86: 93-100.

BRODY, S. 1945. Bioenergetics and growth. Reinhold Publishing Corp., New York. 1023 p.

DEJONGH, H. 1967. Relative growth of the eye in larval and metamorphosing Rana temporaria. Growth 31: 93-103.

EIGENMANN, C. H. and DENNY, W. A. 1900. The eyes of the blind vertebrates of North America. III. The structure and ontogenetic degeneration of the eyes of the Missouri cave salamander, an account based on material collected with a grant from the Elizabeth Thompson Fund. Biol. Bull. 2: 33-41.

HEUTS, M. J. 1951. Ecology, variation, and adaptation of the blind African cave fish Caecobarbus geertsii Blgr. Ann. Soc. Roy. Zool. Belg. 82: 155-230.

HEUTS, M. J. 1953. Regressive evolution in cave animals, p. 290-309. In Symposia of the Society of Experimental Biology. Number VII. Academic Press, New York.

HUMPHREY, R. R. 1922. The multiple testis in urodeles. Biol. Bull. 43: 45-67.

HUMPHREY, R. R. 1926. The multiple testis in Diemyctylus. J. Morphol. Physiol. 41: 283-309.

HUXLEY, J. S. 1932. Problems of relative growth, 1972 unabridged reprint with a new introduction by the author. Dover Publications, Inc., New York. 312 p.

MARTIN, W. R. 1949. The mechanics of environmental control of body form in fishes. University of Toronto Biol. Ser. 58. University of Toronto Press, Toronto, Canada.

MITCHELL, R. W. and REDDELL, J. R. 1965. Eurycea tridentifera, a new species of troglobitic salamander from Texas and a reclassification of Typhlomolge rathbuni. Texas $\mathrm{J}$. Sci. 17: 12-27.

ORGAN, J. A. 1961. Studies of the local distribution, life history, and population dynamics of the salamander genus (Desmognathus) in Virginia. Ecol. Mongr. 31: 189-220.

SIMPSON, G. G., ROE, A. and LEWONTIN, R. C. 1960. Quantitative Zoology. Harcourt, Brace and World, Inc., New York. 440 p.

STONE, L. S. 1964. The structure and visual function of the eye of larval and adult cave salamanders Typhlotriton spelaeus. J. Exp. Zool. 156: 201-218.

TWITTY, V. C. and ELLIOT, H. A. 1934. The relative growth of the amphibian eye, studied by means of transplantation. J. Exp. Zool. 68: 247-291.

TWITTY, V. C. and SCHWIND, J. L. 1931. The growth of eyes and limbs transplanted heteroplastically between two species of Amblystoma. J. Exp. Zool. 59: 61-86. 